\title{
A numerical taxonomic study of the "Streptococcus milleri" group based upon conventional phenotypic tests and pyrolysis mass spectrometry
}

\author{
T. G. WINSTANLEY, J. T. MAGEE*, D. I. LIMB, J. M. HINDMARCH, R. C. SPENCER, \\ R. A. WHILEY†, D. BEIGHTON $\ddagger$ and J. M. HARDIE $†$
}

\begin{abstract}
Bacteriology Department, Royal Hallamshire Hospital, Sheffield S10 2JF, "Department of Microbiology, The Children's Hospital, Sheffield S10 2TH, and tDepartment of Oral Microbiology and $\ddagger$ Hunterian Dental Research Unit, The London Hospital Medical College, London E1 2AD
\end{abstract}

\begin{abstract}
Summary. Clinical strains presumptively identified as Streptococcus milleri (60), and blind coded collection strains (21) were characterised in conventional tests and pyrolysis mass spectrometry. Comparison of the clusters found by these two approaches revealed five clearly distinct centres of variation. Three corresponded to the DNA homology groups suggested by Whiley and Hardie (1989) as representing the species $S$. anginosus, $S$. intermedius and $S$. constellatus; a fourth comprised three Lancefield group $C \beta$-haemolytic strains; the fifth may represent a biotype of $S$. anginosus. The characteristics of the latter group are described.
\end{abstract}

\section{Introduction}

Organisms of the "Streptococcus milleri group" are part of the normal flora of the human oral cavity, upper respiratory, gastrointestinal and female urogenital tracts. ${ }^{1-7}$ They are the most common cause of streptococcal abscesses of the mouth and internal organs, including the brain, liver, lungs and spleen $^{8-15}$ and are also isolated in cases of appendicitis, peritonitis, endocarditis, meningitis, obstetric and neonatal infections, and infections of the skin and soft tissues. ${ }^{5,13,16,17}$ Evidence for the pathogenicity of these streptococci has been reviewed. ${ }^{18-20}$

The " $S$. milleri group" has contained various taxa

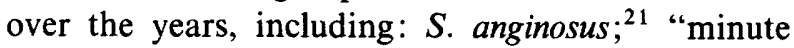
haemolytic streptococci" from the throat; ${ }^{1}$ the human faecal isolates of Smith and Sherman ${ }^{22}$ and the nonhaemolytic Streptococcus $M G .^{2}$ The name $S$. milleri was first introduced by Guthof ${ }^{23}$ to describe a physiologically distinct group of organisms isolated from oral sites which were predominantly of Lancefield group $\mathrm{F}^{24}$ Ottens and Winkler ${ }^{9}$ found the group $\mathrm{F}$ antigen in both haemolytic and non-haemolytic isolates and showed that these could possess any one of five carbohydrate typing antigens.

On the basis of cell wall analysis, numerical taxonomy and DNA transformation, Colman and Williams ${ }^{25}$ proposed a revised description of the " $S$. milleri group", incorporating: S. milleri ${ }^{23}$ all group $\mathrm{F}$ streptococci; Streptococcus MG; certain non-haemolytic streptococci of groups $\mathrm{A}, \mathrm{C}$ and $\mathrm{G}$; strains possessing an Ottens and Winkler ${ }^{9}$ typing antigen but

Received 18 April 1991 ; accepted 24 May 1991. no Lancefield group antigen; and the "minute haemolytic streptococci". ${ }^{1}$

However, this revision was not accepted in the USA, where Facklam ${ }^{26}$ found high similarity between Streptococcus $M G,{ }^{2} S$. intermedius, ${ }^{27} S$. constellatus ${ }^{28}$ and $S$. anginosus, ${ }^{21}$ and divided the " $S$. milleri group" into non- $\beta$-haemolytic lactose fermenters ( $S . M G$ intermedius) and non- $\beta$-haemolytic non-lactose fermenters (S. anginosus-constellatus). Later, ${ }^{29}$ the American nomenclature was revised as follows: $\beta$ haemolytic strains (whether Lancefield group A, C, $\mathrm{G}, \mathrm{F}$ or ungroupable) were called $S$. anginosus; $S . M G$ intermedius became $S$. intermedius; and $S$. anginosusconstellatus became $S$. constellatus.

Workers have disagreed on the homogeneity of the "S. milleri group". Some have found the group to be homogeneous in phenotypic tests ${ }^{11,30-33}$ and DNA hybridisation. ${ }^{32,34-36}$ However, heterogeneity has been reported on the basis of: haemolysis; ${ }^{8,25}$ whole cell trimethylsilyl sugar profiles; ${ }^{37}$ fermentation patterns $;{ }^{5,7}$ long chain fatty acid analysis; $;{ }^{38,39}$ antigenic composition $;{ }^{11,25,40}$ multilocus enzyme electrophoresis $;{ }^{41}$ sodium dodecyl sulphate-polyacrylamide gel electrophoresis (SDS-PAGE) of cellular proteins; ${ }^{\mathbf{4 2}}$ and $\mathrm{G}+\mathrm{C}$ content. $^{43}$

Kilpper-Bälz et al ${ }^{44}$ clearly distinguished the type strains of $S$. constellatus and $S$. anginosus by DNA hybridisation under stringent conditions; $S$. intermedius was also distinct but more similar to $S$. constellatus. Two homology groups were found, one showing high homology with $S$. constellatus and the other with $S$. anginosus. Knight and Shlaes ${ }^{45}$ found evidence of at least three genetically and phenotypically distinguishable groups within 18 representatives of $S$. intermedius. 
Whiley ${ }^{46}$ found that type strains of $S$. anginosus, $S$. constellatus and $S$. intermedius belonged to separate DNA homology groups. Whiley and $\mathrm{Hardie}^{47}$ examined 25 strains by DNA-DNA hybridisation and phenotypic characteristics, finding three genetic groups containing the type strains of $S$. constellatus, $S$. intermedius and $S$. anginosus, respectively; a fourth homology group was later named $S$. parasanguis. ${ }^{48}$ Subsequently, phenotypic discrimination of the three DNA homology groups was demonstrated by enzyme detection tests with fluorogenic substrates that allowed a collection of 157 strains to be identified. ${ }^{49}$ Emended descriptions recognising $S$. anginosus, $S$. constellatus and $S$. intermedius as distinct species have recently been published as a consequence of this work. ${ }^{50}$ This may end the controversy over taxonomy and nomenclature that has impeded attempts to link pathogenicity and clinical source with membership of subgroups of "S. milleri".

In earlier work with coryneform bacteria, ${ }^{51}$ classifications derived from conventional test reaction patterns (CTRPs) and pyrolysis mass spectrometry (PMS) were successfully combined. In the present study, the taxonomy of the " $S$. milleri group" was investigated by a similar combination of approaches. Clinical strains were collected prospectively and a collection of extensively characterised marker strains was obtained for comparison. Previously published DNA-DNA hybridisation data for the collection strains ${ }^{46}$ was used to validate the classification results.

\section{Materials and methods}

\section{Strains}

Eighty-one strains of " $S$. milleri" were examined. Sixty comprised clinical strains isolated in the routine laboratory at the Royal Hallamshire Hospital between April and August, 1990; three were from the upper respiratory tract, 36 from urogenital sites, and 21 from other clinical sources. Two patients yielded paired isolates (laminectomy wound, blood culture; vaginal swab, blood culture) which were examined as duplicate cultures of the same strain. The remainder were strains previously examined in DNA homology studies ${ }^{47}$ and received with coded designations. Three of the latter strains, NCDO 2226, NCDO 2227 and NCTC 10713, were examined in duplicate, one culture as part of the coded collection, and one as a "known" marker strain. The identities of the coded strains were not revealed until cluster analysis had been completed. All strains were presumptively identified as " $S$. milleri". ${ }^{52}$ A further four strains were examined: two strains of $S$. parasanguis, each included once in the coded set and once as a marker strain; one blood culture isolate; and one throat isolate. The latter two were identified in API-20 STREP (API-bioMerieux, France) as $S$. mitis and $S$. sanguis respectively. Strains were stored in glycerol $10 \%$ broth at $-70^{\circ} \mathrm{C}$ and cultured on blood agar (Columbia Agar Base, Oxoid, with horse blood, Difco, $5 \%$ ) (HBA) incubated anaerobically at $37^{\circ} \mathrm{C}$ for $48 \mathrm{~h}$.

\section{Biochemical tests}

Atmospheric requirements were determined by incubation in air, anaerobically, or in $\mathrm{CO}_{2} 7 \%$ in air at $37^{\circ} \mathrm{C}$. Haemolysis, colony size, the uniformity of a slide suspension of 3-5 colonies in saline, and growth at $43^{\circ} \mathrm{C}$ were recorded after anaerobic incubation for $48 \mathrm{~h}$ on HBA. Tolerance of $\mathrm{NaCl} 6.5 \%$, bile salts $10 \%$ and tetracycline $2 \mathrm{mg} / \mathrm{L}$ was determined by agar incorporation methods. Acid production from glycerol, adonitol, inositol, salicin, xylose, fucose, rhamnose, glucose, fructose, galactose, mannose, sucrose, maltose, turanose, melezitose, melibiose and cellobiose was determined with $5 \%$ substrate in API-20 STREP Medium, dispensed in microtitration trays and incubated at $37^{\circ} \mathrm{C}$ for $24 \mathrm{~h}$. Further reactions (acetoin, pyrrolidonyl-arylamidase, $\alpha$-galactosidase, $\beta$-glucuronidase, $\beta$-galactosidase, alkaline phosphatase, leucine arylamidase and arginine dihydrolase production; hippurate and aesculin hydrolysis, and acid production from ribose, L-arabinose, mannitol, sorbitol, lactose, trehalose, inulin, raffinose, starch and glycogen) were determined in the API-20 STREP micro-gallery system. Starch hydrolysis, hyaluronidase production, ${ }^{47} \mathrm{H}_{2} \mathrm{O}_{2}$ production, ${ }^{53} \beta$-fucosidase and $\alpha$-amylase production (A/S Rosco rapid identification tests; Rosco Diagnostika, Taastrup, Denmark) and the presence of Lancefield group antigens A, C, G and $\mathrm{F}^{54}$ were determined. Fluorogenic substrates were used to test for the presence of the enzymes sialidase, $\beta$-D-fucosidase, $\beta$ - $\mathrm{N}$-acetylgalactosaminidase, $\beta$-Nacetylglucosaminidase, $\beta$-galactosidase, $\beta$-glucosidase, $\alpha$-galactosidase and $\alpha$-glucosidase. ${ }^{49}$

\section{Pyrolysis mass spectromety}

Four replicate spectra were obtained for each culture. Methods and mathematical data processing were as described previously. ${ }^{51}$

\section{Taxonomic analysis}

Classification and identification analyses were as described previously. ${ }^{51}$ Briefly, similarity coefficients were the simple matching coefficient for CTRP data and squared Euclidian distance for PMS data; hierarchical clustering was by the unweighted pair group method with arithmetic averages (UPGMA). Cross tabulations of cluster membership in these classifications were examined; clusters were reordered to reflect the similarity matrices, and to optimise matching along a diagonal of correlated cluster membership. This tabulation suggested a unified classification (table I) reflecting the inter-strain similarities found in both PMS and CTRPs. The identities of coded strains were not revealed until the unified 


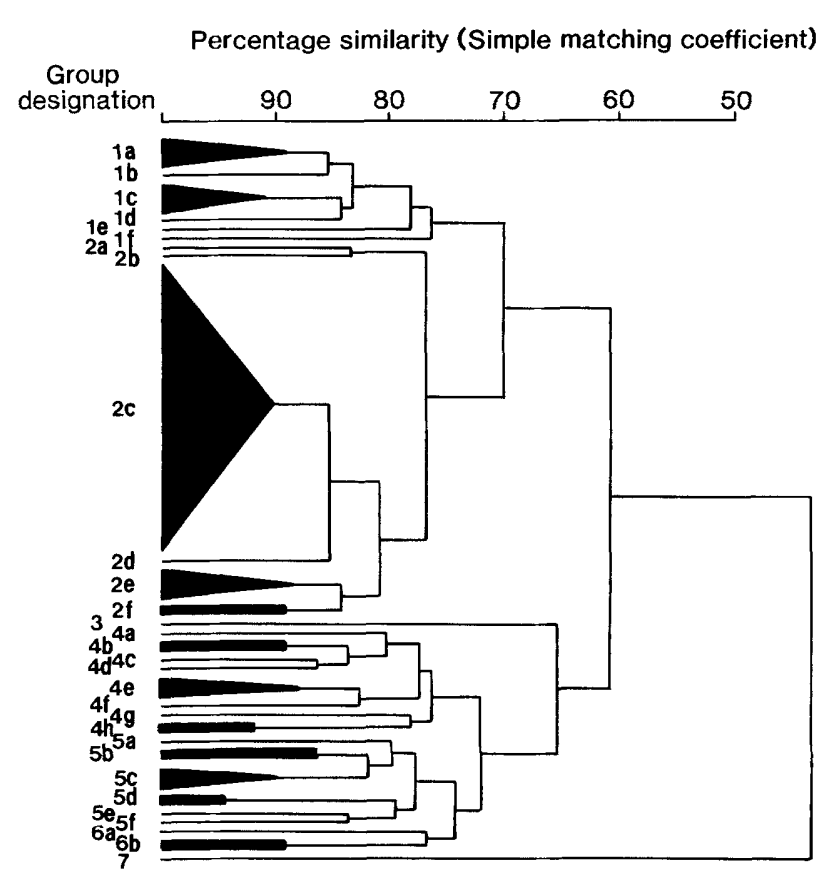

Fig. 1. Dendrogram based on CTRPs. The similarity measure is the simple matching coefficient.

classification was finalised, to minimise the possibility of bias.

\section{Results}

Three strains of " $S$. milleri" were examined as both coded cultures and "known" marker strains, and two clinical strains as paired concurrent isolates. In each case the similarity in PMS was so great as to suggest that the duplicated cultures were indistinguishable. The duplicate cultures of $S$. parasanguis showed similar behaviour. Several pairs of clinical strains also appeared indistinguishable, although there was no documented connection between the patients from whom they originated. The non-milleri streptococci were clearly distinct from the main cluster of " $S$.

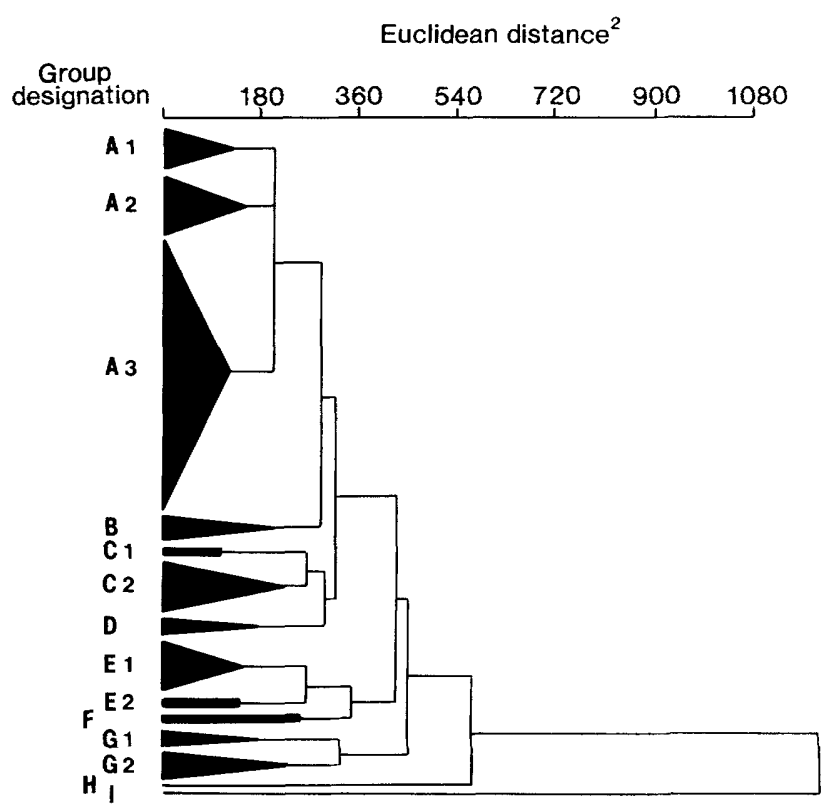

Fig. 2. Dendrogram based on PMS data. The dissimilarity measure is squared Euclidean distance, which is approximately equal to the probability on a $\chi^{2}$ distribution with 19 degrees of freedom that strains were indistinguishable.

milleri" strains in PMS, with a squared Euclidian distance $>1000$. These are not mentioned further.

As in the study of coryneform bacteria,${ }^{51}$ classifications based on CTRPs (fig. 1) and PMS (fig. 2) showed extensive correlation of group membership, revealed by cross-tabulation (table I). As before, this strategy suggested a unified classification, combining the order revealed in the classifications from PMS and CTRP data. The five unified classification blocks are shown in table II, as are PMS cluster, CTRP cluster and block membership for individual strains. CTRPs are shown in table III.

Block 1 comprised fifteen strains including NCDO 2226 (the type strain of S. constellatus), NCTC 5389 and NCTC 10714 ("Streptococcus sp. group F"), NCTC 11063 and AM699 ("S. milleri"). All of these strains are known to be members of DNA homology

Table I. A cross tabulation of group membership in the CTRP and PMS classifications showing the five blocks of the unified classification

\begin{tabular}{|c|c|c|c|c|c|c|c|c|c|c|c|c|c|c|c|}
\hline \multirow{2}{*}{$\begin{array}{l}\text { CTRP } \\
\text { cluster }\end{array}$} & \multicolumn{14}{|c|}{ PMS cluster } & \multirow{2}{*}{ Block } \\
\hline & $\mathbf{H}$ & I & E2 & $\mathrm{F}$ & G2 & $\mathrm{C} 2$ & G1 & $\mathrm{Cl}$ & E1 & B & Al & D & $\mathrm{A} 2$ & A3 & \\
\hline $\begin{array}{c}7 \\
3 \\
4 a-h \\
5 a\end{array}$ & 1 & 1 & 2 & 2 & $\begin{array}{l}1 \\
3\end{array}$ & $\begin{array}{l}4 \\
1 \\
\end{array}$ & & & & & & & & & 1 \\
\hline $\begin{array}{c}1 \mathrm{a}-\mathrm{f} \\
2 \mathrm{a}\end{array}$ & & & & & & $2^{*}$ & 2 & 2 & $\begin{array}{l}5 \\
1 \\
\end{array}$ & & & & $1^{*}$ & & 2 \\
\hline $5 b-f$ & & & & & & & & & & 3 & 6 & & & & 3 \\
\hline $6 a-b$ & & & & & & & & & & & & 3 & & & 4 \\
\hline $2 b-f$ & & & & & & & & & & & & & 6 & 35 & 5 \\
\hline
\end{tabular}

* Unassigned strains; CTRP, conventional test reaction patterns; PMS, pyrolysis mass spectrometry. 
Table II. Origin, API-20 STREP biotype, DNA homology group (HG) and cluster membership for individual strains

\begin{tabular}{|c|c|c|c|c|c|}
\hline \multirow{2}{*}{ Designation } & \multirow{2}{*}{$\begin{array}{c}\text { API } \\
\text { biotype }\end{array}$} & \multirow{2}{*}{ DNA HG } & \multicolumn{2}{|c|}{ Cluster } & \multirow{2}{*}{$\begin{array}{l}\text { Number } \\
\text { of } \\
\text { strains }\end{array}$} \\
\hline & & & CTRP & PMS & \\
\hline \multicolumn{6}{|c|}{ Block 1 (S. constellatus) } \\
\hline NCDO 2226 & I & 1 & $4 \mathrm{a}$ & I & 1 \\
\hline AM699 & I & 1 & $4 d$ & E2 & 1 \\
\hline NCTC 5389 & II & 1 & $4 \mathrm{~g}$ & E2 & 1 \\
\hline NCTC 10714 & I & 1 & $4 \mathrm{c}$ & $\bar{F}$ & 1 \\
\hline \multirow[t]{10}{*}{ NCTC 11063} & I & 1 & $4 b$ & $\mathrm{C} 2$ & 1 \\
\hline & I & & 7 & $\mathbf{H}$ & 1 \\
\hline & I & & $4 b$ & $\mathbf{F}$ & 1 \\
\hline & I & & $4 f$ & G2 & 1 \\
\hline & I & & 3 & G2 & 1 \\
\hline & I & & $4 \mathrm{e}$ & $\mathrm{G} 2$ & 2 \\
\hline & I & & $4 b$ & $\mathrm{C} 2$ & 1 \\
\hline & I & & $4 e$ & $\mathrm{C} 2$ & 1 \\
\hline & I & & $5 \mathrm{a}$ & $\mathrm{C} 2$ & 1 \\
\hline & I & & $4 \mathrm{~h}$ & $\mathrm{C} 2$ & 1 \\
\hline \multicolumn{6}{|c|}{ Block 2 (S. anginosus) } \\
\hline PC4890 & II & 3 & la & G1 & 1 \\
\hline NMH10 & II & 3 & $1 d$ & $\mathrm{Cl}$ & 1 \\
\hline CDC $1007-77$ & II & 3 & la & $\mathrm{Cl}$ & 1 \\
\hline NCTC 11062 & II & 3 & 1a & E1 & 1 \\
\hline CDC $2405-81$ & II & 3 & If & E1 & 1 \\
\hline NCTC 10713 & II & 3 & $2 a$ & E1 & 1 \\
\hline ATCC 9895 & II & 3 & $(\mathrm{lc}$ & E1) & 1 \\
\hline G5:3 & II & 3 & $\{1 c$ & El $\}$ & 1 \\
\hline \multirow[t]{2}{*}{ NCTC 8037} & II & 3 & (lc & E1) & 1 \\
\hline & II & & $1 b$ & G1 & 1 \\
\hline \multicolumn{6}{|c|}{ Block 3 (S. intermedius) } \\
\hline NCDO 2227 & II & 2 & $\int 5 d$ & B & 1 \\
\hline NMH2 & II & 2 & $\{\mathrm{~d}$ & B $\}$ & 1 \\
\hline CDC 415-87 & II & 2 & $5 f$ & B & 1 \\
\hline \multirow[t]{4}{*}{ UNS35 } & II & 2 & $5 b$ & $\mathrm{~A} 1$ & 1 \\
\hline & II & & $5 e$ & A1 & 1 \\
\hline & II & & $5 b$ & $\mathrm{~A} 1$ & 1 \\
\hline & II & & $5 c$ & Al & 3 \\
\hline \multicolumn{6}{|c|}{ Block 4 (undesignated) } \\
\hline & II & & 6 & D & 3 \\
\hline \multicolumn{6}{|c|}{ Block 5 (mannitol fermenting $S$. anginosus) } \\
\hline KR687 & III & 3 & $2 \mathrm{~b}$ & A2 & 1 \\
\hline \multirow[t]{7}{*}{ KR455 } & III & 3 & $\{2 c$ & A2 $\}$ & 1 \\
\hline & III & & $\{2 c$ & $\mathrm{A} 2\}$ & 3 \\
\hline & II & & $2 \mathrm{f}$ & A2 & 1 \\
\hline & II & & $2 \mathrm{f}$ & A3 & 1 \\
\hline & III & & $2 \mathrm{~d}$ & $\mathrm{~A} 3$ & 1 \\
\hline & III & & $2 \mathrm{e}$ & A3 & 4 \\
\hline & III & & $2 \mathrm{c}$ & $\mathrm{A} 3$ & 29 \\
\hline
\end{tabular}

group $1 .{ }^{47}$ Typically, colonies were small $(<0.5 \mathrm{~mm}$ ), $\beta$-haemolytic, adherent, and gave a granular saline suspension. Lancefield antigens $(\mathrm{F})$ and $\mathrm{CO}_{2}$ requirement were detected in only a few strains. Most strains in this block were identified as $S$. milleri biotype I in API-20 STREP, and produced hyaluronidase and $\alpha$ glucosidase but not $\mathrm{H}_{2} \mathrm{O}_{2}$. The block was diverse, comprising strains from CTRP clusters $3,4,5 \mathrm{a}$ and an outlier in cluster 7, which were members of PMS clusters $\mathrm{C} 2, \mathrm{E} 2, \mathrm{~F}, \mathrm{G} 2$ and the outlying clusters $\mathrm{H}$ and I. The outlier in CTRP cluster 7 showed an unusual CTRP (turanose and mannose positive) and was also an outlier in PMS (cluster H).

Block 2 comprised 10 strains, including: NCTC 10713 (the type strain of $S$. anginosus); PC4890, NMH 10, NCTC 11062 and G5:3 (“S. milleri"); CDC 1007-
77 and CDC 2405-81 (S. intermedius); ATCC 9895 and NCTC 8037 (Streptococcus MG). These strains are known to be members of DNA homology group 3, with two exceptions (see block 5). Strains ATCC 9895 , NCTC 8037 and G5:3 were closely similar in PMS and CTRP reactions. Typically, colonies were large, $\alpha$ - or non-haemolytic, non-adherent, and gave a granular saline suspension. Lancefield antigen was detected in most strains, but varied (A, C, G or F); none required $\mathrm{CO}_{2}$. All strains were identified as $S$. milleri biotype II in API-20 STREP, and produced $\mathrm{H}_{2} \mathrm{O}_{2}$ and $\beta$-glucosidase but not hyaluronidase. This block comprised strains from CTRP clusters 1 and 2a, which were members of PMS clusters $\mathrm{Gl}, \mathrm{Cl}$ and $\mathrm{E} 1$.

Block 3 comprised nine strains, including NCDO 2227 (the type strain of $S$. intermedius), CDC 415-87 
Table III. Block percentage positivity in conventional tests

\begin{tabular}{|c|c|c|c|c|c|}
\hline \multirow{2}{*}{ Tests } & \multicolumn{5}{|c|}{$\begin{array}{l}\text { Percent of results positive } \\
\text { in block }\end{array}$} \\
\hline & $\begin{array}{c}1 \\
(15)\end{array}$ & $\begin{array}{c}2 \\
(10)\end{array}$ & $\begin{array}{c}3 \\
(9)\end{array}$ & $\begin{array}{c}4 \\
(3)\end{array}$ & $\begin{array}{c}5 \\
(41)\end{array}$ \\
\hline$\alpha$-Haemolysis & 0 & 80 & 11 & 0 & 83 \\
\hline$\beta$-Haemolysis & 60 & 10 & 0 & 100 & 2 \\
\hline Colonies adherent & 40 & 10 & 0 & 0 & 0 \\
\hline Granular suspension & 67 & 90 & 100 & 100 & 12 \\
\hline Colonies $>0.5 \mathrm{~mm}$ diameter & 20 & 90 & 44 & 0 & 100 \\
\hline $\mathrm{CO}_{2}$ requirement & 13 & 0 & 89 & 33 & 0 \\
\hline Tetracycline resistance & 47 & 10 & 22 & 33 & 98 \\
\hline \multicolumn{6}{|l|}{ Lancefield group: } \\
\hline A & 0 & 20 & 0 & 0 & 0 \\
\hline $\mathrm{C}$ & 0 & 10 & 0 & 100 & 0 \\
\hline G & 0 & 10 & 0 & 0 & 5 \\
\hline $\mathrm{F}$ & 20 & 40 & 0 & 0 & 39 \\
\hline \multicolumn{6}{|l|}{ Hydrolysis of: } \\
\hline hippurate & 0 & 0 & 0 & 0 & 12 \\
\hline aesculin & 0 & 100 & 22 & 0 & 100 \\
\hline starch & 47 & 90 & 44 & 0 & 100 \\
\hline \multicolumn{6}{|l|}{ Production of: } \\
\hline$\alpha$-galactosidase (API) & 0 & 10 & 0 & 0 & 95 \\
\hline $\mathrm{H}_{2} \mathrm{O}_{2}$ & 0 & 100 & 0 & 0 & 0 \\
\hline hyaluronidase & 80 & 0 & 100 & 100 & 0 \\
\hline \multicolumn{6}{|l|}{ Acid from: } \\
\hline ribose & 0 & 0 & 0 & 0 & 12 \\
\hline lactose & 40 & 100 & 100 & 100 & 83 \\
\hline mannitol & 7 & 0 & 0 & 0 & 98 \\
\hline trehalose & 87 & 100 & 100 & 33 & 100 \\
\hline raffinose & 0 & 10 & 0 & 0 & 95 \\
\hline amygdalin & 13 & 60 & 89 & 100 & 100 \\
\hline glycogen & 0 & $\mathbf{0}$ & 11 & 0 & 2 \\
\hline galactose & 67 & 100 & 67 & 66 & 100 \\
\hline melibiose & 7 & 10 & 0 & 0 & 98 \\
\hline fructose & 87 & 100 & 78 & 100 & 100 \\
\hline cellobiose & 7 & 70 & 56 & 0 & 100 \\
\hline salicin & 60 & 100 & 33 & 100 & 100 \\
\hline \multicolumn{6}{|l|}{ API-20 STREP biotype: } \\
\hline I & 93 & 0 & 0 & 0 & 0 \\
\hline II & 7 & 100 & 100 & 100 & 5 \\
\hline III & 0 & 0 & 0 & 0 & 95 \\
\hline \multicolumn{6}{|l|}{ Fluorogenic enzyme tests: } \\
\hline sialidase & 0 & 0 & 100 & 0 & 0 \\
\hline$\alpha$-galactosidase & 7 & 0 & 0 & 50 & 53 \\
\hline$\beta$-galactosidase & 27 & 10 & 100 & 100 & 63 \\
\hline$\alpha$-glucosidase & 100 & 0 & 100 & 100 & 97 \\
\hline$\beta$-glucosidase & 13 & 80 & 50 & 100 & 100 \\
\hline$\beta$-D-fucosidase & 0 & 0 & 100 & 0 & 0 \\
\hline$\beta$-N-acetylgalactosaminidase & 0 & 0 & 100 & 0 & 0 \\
\hline$\beta$-N-acetylglucosaminidase & 0 & 0 & 100 & 0 & 0 \\
\hline
\end{tabular}

All strains grew at $43^{\circ} \mathrm{C}$ and on $\mathrm{NaCl} 6.5 \%$, produced alkaline phosphatase, leucine arylamidase, acetoin and arginine dihydrolase. All but one produced acid from turanose and mannose; all but two produced acid from sucrose, maltose and glucose. No strain produced pyrrolidonyl-arylamidase, $\alpha$-amylase, $\alpha$-fucosidase or $\beta$ glucuronidase. None produced acid from sorbitol, inulin, arabinose, rhamnose, adonitol, xylose, melezitose or fucose. Only one strain showed enhanced growth under anaerobic conditions, and only two produced acid from glycerol. Two strains were bile tolerant.

${ }^{*}$ Block 1, S. constellatus; block 2,S. anginosus; block $3, S$. intermedius; block 4, undesignated; block $5, S$. anginosus (mannitol fermenting); ( $=$ number of strains in block.

(S. intermedius), NMH2 and UNS35 ("S. milleri"), all of which are known to be members of DNA homology group 2. Strains NCDO 2227 and NMH 2 were closely similar in PMS and CTRP patterns. Typically, colonies were non-haemolytic, non-adherent, gave a granular saline suspension, but were variable in size. Lancefield antigen was not detected, and most required
$\mathrm{CO}_{2}$. All strains were identified as $S$. milleri biotype II in API-20 STREP, and produced hyaluronidase, $\beta$-Dfucosidase, $\beta$-N-acetylgalactosaminidase, sialidase, $\beta$ $\mathrm{N}$-acetylglucosaminidase, $\beta$-galactosidase and $\alpha$-glucosidase but not $\mathrm{H}_{2} \mathrm{O}_{2}$. This tight block comprised strains from CTRP clusters $5 b$ to $5 f$, which were members of PMS clusters B and Al.

Block 4 comprised three strains which gave CTRPs similar to those of block 3. However, they produced small, $\beta$-haemolytic colonies, possessed Lancefield group $C$ antigen, and were similar to block 5 strains in the fluorescent substrate enzyme tests (FETs). This tight block comprised strains from CTRP cluster 6, which were members of PMS cluster D. None of these strains was from the reference collection.

Block 5 comprised 41 strains, including KR687 and KR455 ("S. milleri"), i.e., the two remaining known members of DNA homology group 3. Typically, colonies were large, $\alpha$-haemolytic, non-adherent and gave a smooth saline suspension. Many possessed Lancefield group F antigen, and none required $\mathrm{CO}_{2}$. Almost all strains were identified as $S$. milleri biotype III in API-20 STREP, produced acid from a wide range of sugars, and produced $\beta$-glucosidase, $\beta$ galactosidase, $\alpha$-galactosidase and $\alpha$-glucosidase but not hyaluronidase or $\mathrm{H}_{2} \mathrm{O}_{2}$. This was the most homogeneous block of strains in both CTRPs (clusters 2b-f) and PMS (clusters A2 and A3).

Three strains had uncertain affiliations. The coded strain CDC 2236-81 and clinical strain C1084 appeared similar to block 1 in PMS, but to block 2 in CTRPs. CDC 2236-81 is known to be a member of DNA homology group 3. Clinical strain M2792 appeared similar to block 2 in CTRPs, but to block 5 in PMS. All three were similar to block 2 in FETs and were identified as $S$. milleri biotype II in API-20 STREP.

As in the study of coryneforms, ${ }^{51}$ corroboration of the unified classification was sought by comparison of identification results with actual group membership. Strains were divided into two approximately equal sets; the first (teaching) set provided descriptions of the five blocks, and strains of the second (challenge) set were identified by comparison with these descriptions; the sets were then reversed, so that all strains were identified from a challenge set. Inevitably, blind identification of the three strains in block 4 gave poor agreement ( $0 \%$ CTRP, 66\% PMS); the teaching sets comprised at most two strains, a number clearly inadequate to provide a description of block characteristics. With this exception, conventional identifcation in the unified classification gave accurate and unequivocal results (98-100\% agreement, table IV); PMS identification gave acceptable results (70-100\% agreement).

\section{Discussion}

These findings show that the " $S$. milleri group" contains several distinct taxa that can be differentiated 
Table IV. Results of blind identification

\begin{tabular}{|c|c|c|c|}
\hline \multirow{2}{*}{$\begin{array}{c}\text { Block } \\
\text { no. }\end{array}$} & \multirow{2}{*}{$\begin{array}{l}\text { Total } \\
\text { number of } \\
\text { strains }\end{array}$} & \multicolumn{2}{|c|}{$\begin{array}{l}\text { Number of strains showing firm agree- } \\
\text { ment* with block membership for iden- } \\
\text { tifications based on }\end{array}$} \\
\hline & & CTRPs & PMS \\
\hline 1 & 15 & $15(0)$ & $12(3)$ \\
\hline 2 & 10 & $10(0)$ & $7(1)$ \\
\hline 3 & 9 & $9(0)$ & $9(0)$ \\
\hline 4 & 3 & $0(2)$ & $2(1)$ \\
\hline 5 & 41 & $40(1)$ & $41(0)$ \\
\hline
\end{tabular}

* The number of strains yielding equivocal identification results in which the first or second choice identification agreed with the actual block membership are given in parenthesis.

The homogeneity of each block in the unified classification was tested by identifying half the strains on the basis of block descriptions derived from the properties of the remaining half, then repeating this after reversing the 'blind identification' and 'teaching' sets. Identification results based on CTRPs showed firm agreement with actual block membership for $95 \%$ of strains, and those based on PMS showed agreement for $93 \%$ of strains, indicating good homogeneity of biochemical and compositional characters within the blocks. The poor agreement rates for block 4 strains probably reflect the small number of strains, with consequent uncertainty in the description of this block, rather than strain heterogeneity.

in CTRPs and PMS. They confirm the existence of the three species suggested by DNA homology ${ }^{47}$ but add two further groups, one comprising mostly saccharolytic strains, the other comprising Lancefield group $C \beta$-haemolytic strains producing minute colonies. Each of the five groups appeared homogeneous and distinct.

In common with Whiley et al., ${ }^{49}$ we noted an association between the production of hyaluronidase and $\beta$-haemolysis activity among $S$. constellatus (block 1) strains but not among $S$. intermedius (block 3 ) strains that produced hyaluronidase but were not $\beta$-haemolytic.

Phenotypic tests that differentiated between the blocks particularly well were: production of $\alpha$-galactosidase in API-20 STREP, hyaluronidase, $\mathrm{H}_{2} \mathrm{O}_{2}$ and acid from mannitol, raffinose or melibiose, together with hydrolysis of aesculin. These tests were technically undemanding and gave clear-cut results. A similar discriminatory scheme was suggested by Whiley and Hardie. ${ }^{47}$ Alternatively, a battery of six of the FETs described by Whiley et al. ${ }^{49}$ could be used. These were: production of sialidase (or $\beta$-D fucosidase or $\beta$-N-acetylgalactosaminidase), $\beta$-N-acetylglucosaminidase, $\beta$-galactosidase, $\alpha$-galactosidase, $\beta$-glucosidase and $\alpha$-glucosidase. Discriminatory characters are listed in table V.

\section{References}

1. Long PH, Bliss EA. Studies upon minute hemolytic streptococci. I. The isolation and cultural characteristics of minute betahemolytic streptococci. J Exp Med 1934; 60: 619-631

2. Mirick GS, Thomas L, Curnen EC, Horsfall FL. Studies on a non-hemolytic streptococcus isolated from the respiratory tract of human beings. I. Biological characteristics of Streptococcus MG. J Exp Med 1944; 80 : 391-407.
Table V. Discriminatory characters for the unified classification blocks

\begin{tabular}{|c|c|c|c|c|c|}
\hline \multirow{2}{*}{ Tests } & \multicolumn{5}{|c|}{$\begin{array}{l}\text { Results obtained with } \\
\text { strains of block* }\end{array}$} \\
\hline & 1 & 2 & 3 & 4 & 5 \\
\hline $\mathrm{H}_{2} \mathrm{O}_{2}$ & - & + & - & - & - \\
\hline Aesculin & - & + & $\mathrm{d}$ & - & + \\
\hline Hyaluronidase & d & - & + & + & - \\
\hline$\beta$-Haemolysis & d & - & - & + & - \\
\hline Lancefield group C & - & - & - & + & - \\
\hline Mannitol $\dagger$ & - & - & - & - & + \\
\hline$\alpha$-Galactosidase (API) & - & - & - & - & + \\
\hline \multicolumn{6}{|l|}{ Fluorogenic enzyme: } \\
\hline sialidase & - & - & + & - & - \\
\hline$\alpha$-galactosidase & - & - & - & $\mathrm{d}$ & d \\
\hline$\beta$-galactosidase & d & - & + & + & d \\
\hline$\alpha$-glucosidase & + & - & + & + & + \\
\hline$\beta$-glucosidase & - & $\mathrm{d}$ & $\mathrm{d}$ & + & + \\
\hline
\end{tabular}

* Results are shown as,-+ or $\mathrm{d}$, corresponding to $<15 \%,>85 \%$ or $15-85 \%$ positivity. Block $1, S$. constellatus; block $2, S$. anginosus; block $3, S$. intermedius; block 4, undesignated; block 5 , mannitol fermenting $S$. anginosus.

$\dagger$ Raffinose and melibiose yield similar results.

$\ddagger \beta$-D-fucosidase, $\beta$-N-acetylgalactosaminidase and $\beta$ - $N$-acetylglucosaminidase gave similar results.

The controversy over the taxonomy and nomenclature of the " $S$. milleri group" has been largely resolved by evidence from newer taxonomic techniques. However, some effort should now be directed towards ensuring that the range of species and subspecies of the group has been adequately documented. We could find no convincing match between the CTRPs of the blocks and the classification of Facklam. ${ }^{29}$ However, blocks 1-3 corresponded to the DNA homology groups which Whiley and Hardie ${ }^{47}$ termed $S$. constellatus, $S$. anginosus and $S$. intermedius, respectively. The evidence presented here suggests that there is a previously undescribed centre of variation, the group $C \beta$ haemolytic strains of block 4 , and gives clear evidence that the mannitol fermenting strains of $S$. milleri form a compact group or phenon, closely similar in conventional tests and PMS. The latter biotype has been reported previously, ${ }^{5,7,8,43}$ Two of the block 5 strains (KR687 and KR455) have shown high DNA homology with the type strain of S. anginosus ${ }^{47}$ and further DNA hybridisation work is required to confirm this relationship. Also, similar work on a larger collection of strains showing the phenotypic characters of strains in block 4 is required to elucidate their taxonomic position.

3. Attebury HR, Sutter VL, Finegold SM. Effect of a partially chemically defined diet on normal human fecal flora. $A m J$ Clin Nutr 1972; 25: 1391-1398.

4. Mejàre B, Edwardsson S. Streptococcus milleri (Guthof); an indigenous organism of the human oral cavity. Arch Oral Biol $1975 ; 20$ : 757-762.

5. Poole PM, Wilson G. Occurrence and cultural features of Streptococcus milleri in various body sites. J Clin Pathol 1979; 32: 764-768. 
6. Unsworth PF. The isolation of streptococci from human faeces. J Hyg 1980; 85: 153-164.

7. Ruoff KL, Kunz LJ. Identification of viridans streptococci isolated from clinical specimens. J Clin Microbiol 1982; 15 920-925.

8. Ball LC, Parker MT. The cultural and biochemical characters of Streptococcus milleristrains isolated from human sources. J Hyg 1979; 82: 63-78.

9. Ottens $\mathrm{H}$, Winkler KC. Indifferent and haemolytic streptococci possessing group-antigen F. J Gen Microbiol 1962; 28: 181191.

10. Bateman NT, Eykyn SJ, Phillips I. Pyogenic liver abscess caused by Streptococcus milleri. Lancet 1975; 1:657-659.

11. Lütticken R, Wendorff U, Lütticken D, Johnson EA, Wannamaker LW. Studies on streptococci resembling Streptococcus milleri and on an associated surface-protein antigen. $J$ Med Microbiol 1978; 11: 419-431.

12. De Louvois J. Bacteriological examination of pus from abscesses of the central nervous system. J Clin Pathol 1980; 33: 6671

13. Singh KP, Morris A, Lang SD, MacCulloch DM, Bremner DA Clinically significant Streptococcus anginosus (Streptococcus milleri) infections: a review of 186 cases. NZ Med J 1988 ; $101: 813-816$.

14. Chua D, Reinhart HH, Sobel JD. Liver abscess caused by Streptococcus milleri. Rev Infect Dis 1989; 11 : 197-202.

15. Murray HW, Gross KC, Masur H, Roberts RB. Serious infections caused by Streptococcus milleri. Am J Med 1978; 64: 759-764

16. Koepke JA. Meningitis due to Streptococcus anginosus (Lancefield group F). J AMA 1965; 193: 739-740.

17. Van der Auwera P. Clinical significance of Streptococcus milleri. Eur J Clin Microbiol 1985; 4: 386-390.

18. Gossling J. Occurrence and pathogenicity of the Streptococcus milleri group. Rev Infect Dis 1988; 10: 257-285.

19. Ruoff KL. Streptococcus anginosus ('Streptococcus milleri'): the unrecognized pathogen. Clin Microbiol Rec 1988; 1: 102108

20. Whitworth JM. Lancefield group F and related streptococci. $J$ Med Microbiol 1990; 33: 135-151.

21. Andrewes FW, Horder TJ. A study of the streptococci pathogenic for man. V. A consideration of certain important diseases associated with streptococcal infections in relation to the foregoing types. Lancet 1906; 2: 779-782.

22. Smith FR, Sherman JM. The hemolytic streptococci of human feces. J Infect Dis 1938; 62: 186-189.

23. Guthof O. Ueber pathogene 'vergrünende Streptokokken': Streptokokken-Befunde bei dentogenen Abszessen und infiltraten im Bereich der Mundhöhle. Zbl Bakt Hyg IOrig A 1956; 166: 553-564.

24. Winkler KC, van Amerongen J. Bacteriologic results from 4000 root canal cultures. Oral Surg Oral Med Oral Pathol 1959; 12: $857-875$.

25. Colman G, Williams REO. Taxonomy of some human viridans streptococci. In: Wannamaker LW, Matsen JM (eds) Streptococci and streptococcal diseases: recognition, understanding and management. New York, Academic Press. 1972: 281-299.

26. Facklam RR. Physiological differentiation of viridans streptococci. J Clin Microbiol 1977; 5: 184-201.

27. Prévot AR. Les streptocoques anaérobies. Ann Inst Pasteur (Paris) $1925 ; 39: 417-447$

28. Holdeman LV, Moore WEC. New genus, Coprococcus, twelve new species, and emended descriptions of four previously described species of bacteria for human feces. Int $J$ Syst Bacteriol 1974; 24 : 260-277.

29. Facklam RR. The major differences in the American and British streptococcal taxonomy schemes with special reference to Streptococcus milleri. Eur J Clin Microbiol 1984; 3: $91-93$.

30. Mejare B. Characteristics of Streptococcus milleri and Streptococcus mitior from infected root canals. Odontologisk Revy 1975; 26: 291-308

31. Labbe M, Van der Auwera P, Glupczynski Y, Crockaert F, Yourassowsky E. Fatty acid composition of Streptococcus milleri. Eur J Clin Microbiol 1985; 4: 391-393.

32. Coykendall AL, Wesbecher PM, Gustafson KB. 'Streptococcus milleri', Streptococcus constellatus, and Streptococcus inter- medius are later synonyms of Streptococcus anginosus. Int J Syst Bacteriol 1987; 37: 222-228.

33. French GL, Talsania H, Charlton JRH, Phillips I. A physiological classification of viridans streptococci by use of API-20 STREP system. J Med Microbiol 1989; 28: 275-286.

34. Welborn PP, Hadley WK, Newbrun E, Yajko DM. Characterization of strains of viridans streptococci by deoxyribonucleic acid hybridization and physiological tests. Int J Syst Bacteriol 1983; 33: 293-299.

35. Farrow JAE, Collins MD. Taxonomic studies on streptococci of serological group $\mathrm{C}, \mathrm{G}$ and $\mathrm{L}$ and possibly related taxa. Syst Appl Microbiol 1984; 5: 483-493.

36. Ezaki T, Facklam R, Takeuchi N, Yabuuchi E. Genetic relatedness between the type strain of Streptococcus anginosus and minute-colony-forming beta-hemolytic streptococci carrying different Lancefield grouping antigens. Int J Syst Bacteriol 1986; 36: 345-347.

37. Aluyi HS, Drucker DB. Trimethylsilyl-sugar profiles of Streptococcus milleri and Streptococcus mitis. J Appl Bacteriol $1983 ; 54: 391-397$

38. Drucker DB, Lee SM. Fatty acid fingerprints of 'Streptococcus milleri', Streptococcus mitis, and related species. Int J Syst Bacteriol 1981; 31 : 219-225.

39. Cookson B, Talsania H, Chinn S, Phillips I. A qualitative and quantitative study of the cellular fatty acids of 'Streptococcus milleri' with capillary gas chromatography. $J$ Gen Microbiol 1989; 135: 831-838.

40. Yakushiji T, Konagawa R, Oda M, Inoue M. Serological variation in oral Streptococcus milleri. J Med Microbiol 1988; 27: 145-151.

41. Gilmour MN, Whittan TS, Kilian M, Selander RK. Genetic relationships among the oral streptococci. J Bacteriol 1987; 169: 5247-5257.

42. Whiley RA, Hardie JM, Jackman PJH. SDS-polyacrylamide gel electrophoresis of oral streptococci. In: Holm SE Christensen P (eds) Basic concepts of streptococci and streptococcal diseases. Chertsey, Surrey, Reedbooks. 1982: 61-62.

43. Drucker DB, Lee SM. Possible heterogeneity of Streptococcus milleri determined by DNA mol\% (guanine plus cytosine) measurement and physiological characterization. Microbios $1983 ; 38$ : 151-157.

44. Kilpper-Bälz R, Williams BL, Lütticken R, Schleifer KH Relatedness of 'Streptococcus milleri' with Streptococcus anginosus and Streptococcusconstellatus. Syst Appl Microbiol $1984 ; 5: 494-500$.

45. Knight RG, Shlaes DM. Physiological characteristics and deoxyribonucleic acid relatedness of Streptococcus intermedius strains. Int J Syst Bacteriol 1988; 38: 19-24.

46. Whiley RA. A taxonomic study of oral streptococci. London, PhD thesis. 1987.

47. Whiley RA, Hardie JM. DNA-DNA hybridization studies and phenotypic characteristics of strains within the 'Streptococcus milleri group'. J Gen Microbiol 1989; 135: 2623-2633.

48. Whiley RA, Fraser HY, Douglas CWI, Hardie JM, Williams AM, Collins MD. Streptococcus parasanguis sp. nov., an atypical viridans Streptococcus from human clinical specimens. FEMS Microbiol Lett 1990; 56: 115-121.

49. Whiley RA, Fraser H, Hardie JM, Beighton D. Phenotypic differentiation of Streptococcus intermedius, Streptococcus constellatus, and Streptococcus anginosus strains within the 'Streptococcus milleri group'. J Clin Microbiol 1990; 28: $1497-1501$.

50. Whiley RA, Beighton D. Emended descriptions and recognition of Streptococcus constellatus, Streptococcus intermedius, and Streptococcus anginosus as distinct species. Int $J$ Syst Bacteriol 1991; 41 : 1-5.

51. Hindmarch JM, Magee JT, Hadfield MA, Duerden BI. A pyrolysis-mass spectrometry study of Corynebacterium spp. J Med Microbiol 1990; 31 : 137-149.

52. Ruoff KL, Ferraro MJ. Presumptive identification of 'Streptococcus milleri' in 5 h. J Clin Microbiol 1986; 24 : 495- 497.

53. Whiley RA, Hardie JM. Streptococcus vestibularis sp. nov. from the human oral cavity. Int J Syst Bacteriol 1988; 38: 335339.

54. Dabbs DJW, Pease AA. Beta haemolytic streptococci: single colony grouping by a rapid, simplified coagglutination technique. Med Lab Sci 1984; 41 : 52-54. 